\title{
A Preliminary Characterization of Eco-Innovators and Eco-Designers in Slovenia
}

\section{Preliminarno istraživanje obilježja ekoinovacija i ekodizajna u Sloveniji}

\author{
Preliminary paper • Prethodno priopćenje \\ Received-prispjelo: 7. 12. 2015. \\ Accepted-prihvaćeno: 5. 5. 2016. \\ UDK: $630 * 079$ \\ doi:10.5552/drind.2016.1546
}

\begin{abstract}
Eco-innovation is crucial to Europe's economic competitiveness; environment-friendly technologies have a positive impact on businesses and contribute to job creation. A survey of perceptions and attitudes about eco-innovation and eco-design among 712 Slovenian enterprises was conducted. The survey included micro, small and medium enterprises, and large companies. Analysis of the survey revealed that eco-design in Slovenia is underexploited. Only approximately $50 \%$ of the 657 respondents have established an innovative environment for sustainable development or support for eco-innovation processes. Based on the survey results, it was concluded that further development and promotion will require comprehensive policies at the local and national levels. Specifically, policy solutions should advocate combining eco-innovation and adopting a life-cycle design approach. These policies could result in the development of successful innovations at a breakthrough level. Eco-innovation and eco-design present Slovenian enterprises with the opportunity to create new markets where they could dominate and prosper. Furthermore, Slovenia could become an important contributor to the European Union goal of becoming a smart, sustainable, and inclusive economy by fully satisfying the objectives of four "Europe 2020" Flagship initiatives, while simultaneously contributing to reducing climate change.
\end{abstract}

Key words: eco-design, eco-innovations, opinion, market potential, analysis, Slovenia

SAŽETAK • Ekoinovacije imaju ključno značenje za ekonomsku konkurentnost Europe; okolišno prihvatljive tehnologije pozitivno utječu na poslovanje poduzeća i pridonose stvaranju novih radnih mjesta. Istraživanje percepcije i stajališta o ekoinovacijama i ekodizajnu provedena su u 712 slovenskih poduzeća. Istraživanjem su obuhvaćena mikropoduzeća, mala i srednja poduzeća te velike tvrtke. Analiza rezultata ankete pokazala je da je ekodizajn u Sloveniji nedovoljno iskorišten. Samo je oko 50 \% od 657 anketiranih tvrki uspostavilo inovativno okruženje za održivi razvoj ili uvelo potpore za ekološke inovacijske procese. Na temelju rezultata istraživanja zaključeno je da daljnji razvoj i promocija ekoinovacija i ekodizajna zahtijevaju opsežne politike na lokalnoj i nacionalnoj razini. Naime, politička rješenja trebaju promicati kombinaciju ekoinovacija i usvajanje novog pristupa dizajnu uzimajući u obzir životni ciklus proizvoda. Takve politike mogu dovesti do razvoja uspješnih inovacija. Ekoinovacije $i$

\footnotetext{
Author is assistant professor at University of Ljubljana, Department of Wood Science and Technology, Biotechnical Faculty, Ljubljana, Slovenia. ${ }^{2}$ Author is professor at University of British Columbia, Faculty of Forestry, Vancouver, BC Canada. ${ }^{3}$ Author is associate professor at University of Ljubljana, Faculty of Architecture, Ljubljana, Slovenia.

${ }^{1}$ Autorica je docentica Sveučilišta u Ljubljani, Odsjek za znanost o drvu i drvnu tehnologiju, Biotehnički fakultet, Ljubljana, Slovenija. ${ }^{2}$ Autor je profesor Sveučilišta British Columbia, Šumarski fakultet, Vancouver, BC Kanada. ${ }^{3}$ Autorica jeizvanredna profesorica Sveučilišta u Ljubljani, Arhitektonski fakultet, Ljubljana, Slovenija.
} 
ekodizajn za slovenska su poduzeća prilika za stvaranje novih tržišta na kojima bi mogli dominirati i napredovati. Nadalje, Slovenija bi mogla postati važan čimbenik u ostvarenju težnje Europske unije da postane pametno, održivo i inkluzivno gospodarstvo i da u potpunosti zadovolji ciljeve četiriju ključnih inicijativa strategije „Europa 2020”, a da pritom istodobno pridonosi smanjenju klimatskih promjena.

Ključne riječi: ekodizajn, ekoinovacije, mišljenje, tržišni potencijal, analiza, Slovenija

\section{INTRODUCTION}

\section{UVOD}

Increased need for sustainable development has spurred many changes in the ways commercial activities are now organized. Numerous interventions - spanning over a product's entire life cycle stages from raw material extraction to the end consumption (Berkhout and Smith, 1999; Massard et al., 2014; Glavonjić and Oblak, 2012) - have been devised to reduce environmental impact of these activities so that a harmonious balance between economic development and environmental well-being can be achieved. Many of these interventions have resulted in new products, new processes, and new business systems- all aimed at reducing industrial footprint on the global environment. Collectively, these environmentally friendlier new products, new processes, and new business systems are labeled as eco-innovations (Klewitz and Hansen, 2014), and are considered crucial in global efforts to achieve dynamic sustainability in different aspects (Braungart et al., 2007; Baumgartner, 2011; Ojurović et al., 2013; Pujari, 2006; Oblak and Glavonjić, 2014).

Defining eco-innovation is not a trivial task, although several definitions have been proposed (Fussler and James, 1996; Charter and Clark, 2007; Oblak and Jošt, 2011; Kemp and Pearson, 2007; Berginc et al., 2011; Carrillo-Hermosilla et al., 2010). In general, these definitions emphasize that eco-innovations reduce the environmental impact caused by consumption and production activities, whether the main motivation for their development or deployment is environmental or not. The Organization for Economic Co-operation and Development (OECD) provided a more precise definition of eco-innovation by highlighting the two characteristics that distinguish it from typical innovation. First, it is an innovation that reflects the concept explicit emphasis on a reduction of environmental impact, whether such an effect is intended or not, and second, it is not limited to innovation in products, processes and organizational methods, but also includes innovation in social and institutional structures (OECD, 2009). Therefore, eco-innovation comprises all forms of innovation activities that result in or are directed at improved environmental protection. An eco-innovation has three aspects: a target, which is the main focus of the innovation; a mechanism, which is the method for changing the target; and impacts, which are the resulting effects on environmental conditions (OECD, 2009). Correspondingly, companies focusing on innovations with these aspects are considered eco-innovative companies. Integral to eco-innovation is the concept of eco-design. It is an approach to product design with special consideration for the environmental im- pacts of the product throughout its entire lifecycle. Eco-design developed as a response to growing concern and understanding of the ecological impact of production.

Previous research has predominantly focused on examining eco-innovations at the level of individual firms. For example, Pirc Barčić et al. (2011) examined innovation and innovativeness in the medium-low tech wood industry in the U.S. Additionally, Pirc Barčić and Motik (2013) identified the connection between the concepts of innovation and innovativeness of certain internal and external company factors. Others have examined consumer response to eco-innovations. For example, Rehfeld et al. (2007) found high prices remain the largest obstacle for consumers of environmental products. However, Toppinen et al. (2013) analyzed consumer perceptions of the environmental and social sustainability of wood products in the Finnish market and found out that consumers are more willing to pay more for environmentally and socially sustainable products. Green et al. (1994) empirically analyzed the characteristics of firms in the UK participating voluntarily in a public program that aimed at the promotion of environmental product and process innovations. Rennings et al. (2006) focused on the influence of different characteristics of the EU environmental management and auditing scheme (EMAS) on technical environmental innovations and concluded that a careful design of EMAS is important for environmental and performance facility.

Amidst this growing body of literature, general characterization of eco-innovative companies is not fully considered, particularly pertaining to countries that are not economically prominent, yet are environmentally progressive. Slovenia presents a great example of such a context. The country has a small share in global trade, has recently transitioned to a capitalistic society wherein innovation and private entrepreneurship is more prevalent, and is now part of European Union where environmental standards are very well established. The primary purpose of this paper is to map out general characterization of eco-innovation in Slovenia.

\subsection{European eco-industries and eco-innovation} 1.1. Europska ekoindustrija i ekoinovacije

All enterprises, including service enterprises, engaging in energy- and environment-related activities as their core source of income, are considered eco-industries (European Commission, 2013). The European Commission distinguishes amongst two broad categories of eco-industries. The first consists of small and innovative companies concerned with renewable energy, waste recycling, environmental auditing and consultancy; the second consists of more capital intensive 
enterprises providing goods and services in specific areas such as waste, wastewater, transport.

The eco-industry has grown to become one of Europe's biggest industrial sectors. Pollution management, which encompasses technologies and services in waste management, air pollution control, soil remediation, and recycling, along with resource management, which includes renewable energy plants and water supply, are currently the two most important sectors of eco-industry. The eco-industry contributes to economic growth, employment in the EU and focuses on policies promoting a cleaner environment. The sector covers approximately $2.5 \%$ of the EU's Gross Domestic Product (GDP) and has an annual turnover of around EUR 550 million. Employment in eco-industries was estimated to be around 3.4 million people, which represents around $1 \%$ of the total workforce (Eco-Innovation Action Plan, 2012).

Furthermore, annual growth in employment is trending upwards, most notably in the field of renewable energy and recycling (European Commission, 2014). Rademaekers et al. (2012) showed that improving resource efficiency leads to job creation. However, many of these new jobs will require retraining existing workers rather than create jobs for additional workers.

Europe controls a significant share of certain segments of the global eco-industry market: more than 70 $\%$ in the global market for solar power plants and automated materials separation. The global market for ecoindustries was valued at roughly EUR 1.15 trillion per year in 2010. Furthermore, there is broad consensus that the global market could nearly double to EUR 2 trillion per year by 2020 . The EU is also a leader in R\&D in the area of synthetic biofuels and energy storage technologies (European Commission, 2011b). With more than 3 million employees in the eco-industry, and with the growing demand for environmentally-friendly products and services, Europe is well positioned to meet the environmental challenges of the future.

Given that green technologies have a favorable impact on companies and contribute to job creation, eco-innovation is vitally important to Europe's economic competitiveness. The implementation of ecodesign within European industries would further contribute to the EU transition into a smart, sustainable, and inclusive economy, fully following the objectives of four Europe 2020 Flagship initiatives. Through research and development of new innovative products and services, in close transnational cooperation with academia, research institutes and industry, the EU industrial eco-design approach has the potential to address key action points of the EU's "Innovation Union" initiative. Furthermore, "A resource-efficient Europe" initiative (especially the Low-carbon economy 2050 roadmap, Roadmap to a Resource Efficient Europe, and Strategy for the sustainable competitiveness of the EU construction sector) could be addressed through the promotion of use of renewable materials. Widespread implementation of eco-design practices would also directly contribute to the realization of the "An industrial policy for the globalization era" initiative
(European Commission, 2014), where the industrial competitiveness is the cornerstone of the EU 2020 Industrial policy ("Industry must be placed center stage if Europe is to remain a global economic leader"). European support of eco-innovations in the industry is clear, and directed; for example, in 2008, Europe's first public funding opportunity specifically addressing eco-innovations was announced (CIP-Eco innovation, 2013).

The EU recently developed the Eco-Innovation Scoreboard (Eco-IS), which assesses and rates the ecoinnovation performance of an individual country compared with other EU member states and the EU as a whole. The index is based on 16 indicators, which are aggregated into five components: eco-innovation inputs, eco-innovation activities, eco-innovation outputs, environmental outcomes, and socio-economic outcomes. These ratings indicate the overall performance of individual member states in different dimensions of eco-innovation compared to the EU average. The EcoIS also presents the strengths and weaknesses of each member state. The Eco-IS complements other methods of measuring innovativeness and aims to promote a holistic view on economic, environmental and social performance (Eco-Innovation Observatory, 2014). The actions taken in Europe to support eco-innovation clearly demonstrate that eco-innovation as well as ecodesign already plays critical roles in European efforts to achieve a sustainable and low carbon economy.

\subsection{Slovenia and eco-innovation}

1.2. Slovenija i ekoinovacije

Slovenia lacks a coherent policy framework to systematically encourage energy efficiency, resource efficiency, and system eco-innovations. In fact, no specific policy to support eco-innovations has been developed. However, eco-innovations are being (indirectly) supported by different measures adopted within various policies (innovation, environmental, economic). Support from these policies has resulted in increased investments by Slovenian enterprises into innovation.

In the last five years, $97 \%$ of all Slovenian companies have introduced at least one innovation to reduce production costs, compared with $86 \%$ overall in the EU (European Commission, 2011a). Slovenian companies have introduced an average of 3.6 material cost reduction innovations over the last five years. Among Slovenian companies that introduced an ecoinnovation in their production processes in 2010 and 2011, $4 \%$ found they reduced consumption of input materials by over $40 \%$ (the same figure as in the EU overall). A reduction in consumption of $5 \%$ to $19 \%$ was recorded by $46 \%$ of companies, while only $4 \%$ of Slovenian companies that have successfully introduced an eco-innovation failed to reduce production costs (European Commission, 2011a).

Although Slovenian enterprises do invest in ecoinnovations, Slovenia is not among the leaders in the development of green technologies. The Eco-IS ranks Slovenia's overall eco-innovation performance slightly above the average performance of all 27 EU Member States (see Fig. 1). 


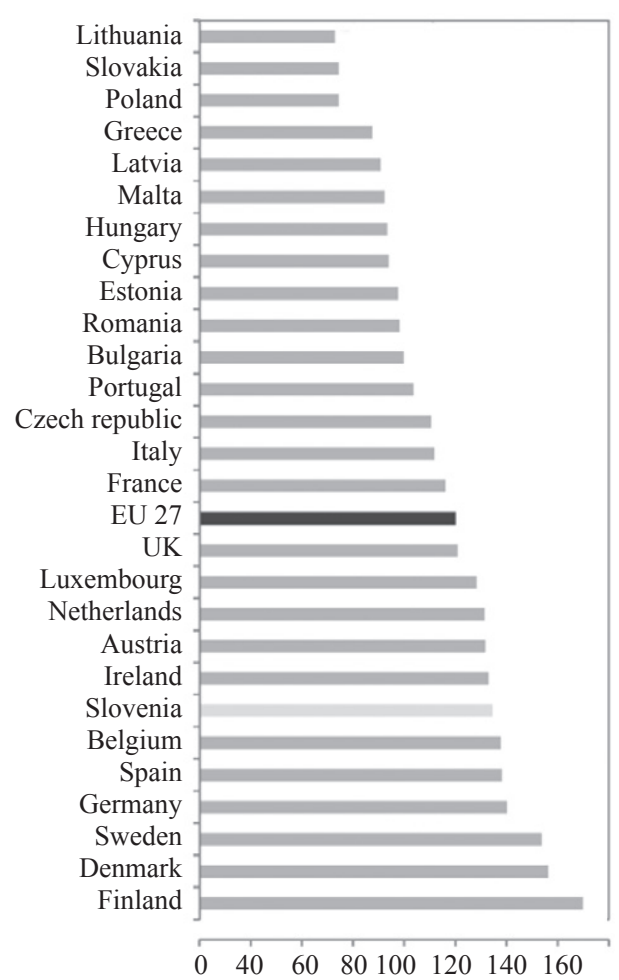

Figure 1 EU27 Eco-Innovation Scoreboard (Eco-IS) results for the 2011: composite index (Eco-Innovation Observatory, 2014)

Slika 1. Rezultati ekoinovacija EU27 (Eco-IS) za 2011. godinu: kompozitni indeks (Eco-innovation observatory, 2014.)

The Eco-IS Socio-economic outcomes indicator is interesting, especially as Slovenia leads EU in this category but underperforms in the eco-innovation inputs category (see Fig. 2). Underperformance in this area may stem from the fact that Slovenia has not identified eco-innovation as a priority horizontal approach to simultaneously improving national economic competitiveness and developing new products and services. As of 2013, $54 \%$ of Slovenian SMEs have not been planning to begin developing green products or services (Flash Eurobarometer 381, 2013). Unfortunately, Eco-innovations in Slovenia are sporadic and limited to only several progressive and export-oriented companies (Eco-innovation observatory, 2014). For example, the goal of making buildings more energy efficient is a challenge for the construction industry, but also presents an opportunity for innovative concepts and for building and device technologies. One reason for Slovenia's moderate rating on the Eco-IS may be ineffective research and development, and poor collaboration between academic institutions and the industry. Furthermore, Slovenia lacks a coherent policy framework to systemically encourage eco-innovations and change production and consumption patterns. However, since investments in eco-innovation (technological and nontechnological) are a requirement of developing green products, a well-managed approach in this area would be needed on the national level. To exploit the transition to a green economy, Slovenia must take a systematic approach to promoting development areas, where it has abundant skills, raw materials, technology, etc. After all, advancing eco-innovations is one of the key opportunities for Slovenia, as it is for other member states, to successfully contribute to the objectives of the EU 2020 strategy.

It is against this background that a survey was conducted to characterize eco-innovative companies in Sloveina, as shown below, and then outline the results of the survey.

\section{MATHERIAL AND METHODS}

2. MATERIJAL I METODE

The Ministry of Economic Development and Technology of the Republic of Slovenia conducted an anonymous web-based survey covering eco-design and eco-innovations for small and medium-sized enterprises and large companies. The questionnaire was devel-

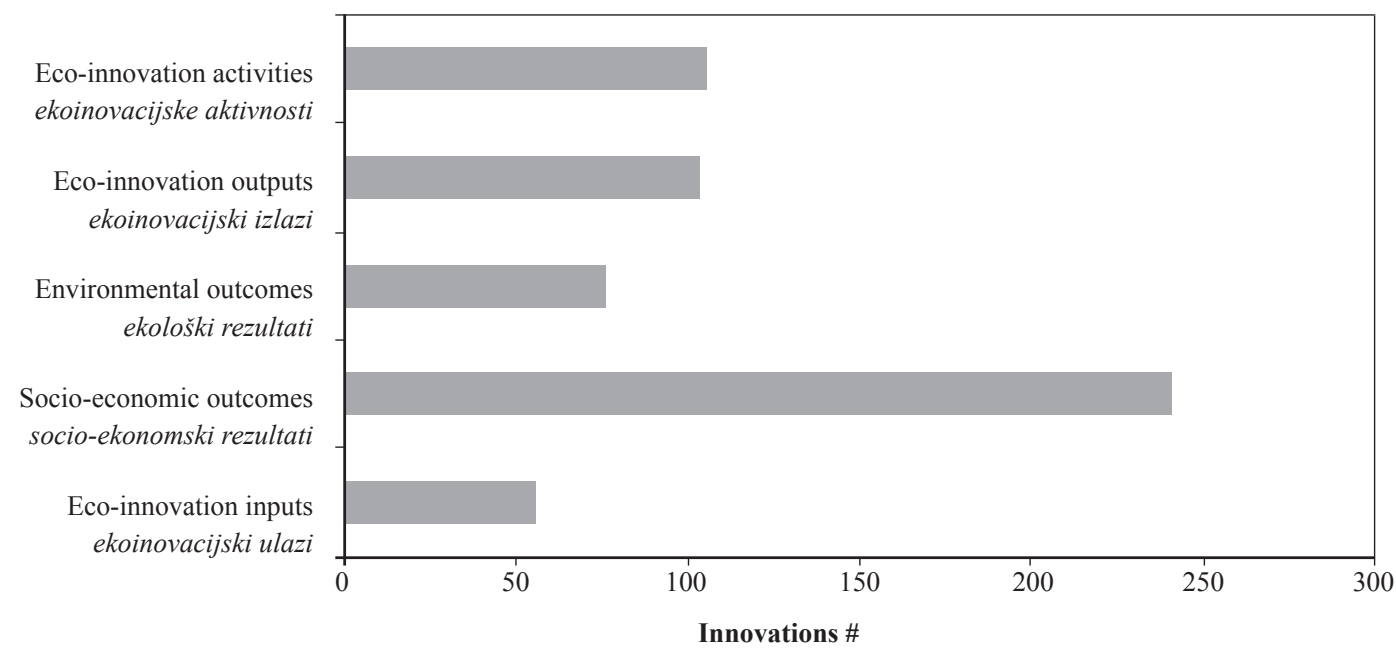

Figure 2 Components of the eco-innovation composite index for Slovenia, 2013 (EU average $=100)($ Eco-Innovation Observatory, 2014)

Slika 2. Sastavnice ekoinovacijskoga kompozitnog indeksa za Sloveniju, 2013. (prosjek EU = 100) $($ Eco-innovation observatory, 2014.) 
Table 1 The eco-innovation related questions used in the survey and frequency of responses to each question

Tablica 1. Pitanja iz ankete vezana za ekoinovacije i broj odgovora na svako od njih

\begin{tabular}{|c|c|c|}
\hline & Question / Pitanje & $\begin{array}{l}\text { Frequency } \\
\text { Broj odgovora }\end{array}$ \\
\hline 1. & $\begin{array}{l}\text { Does your company have a department/officer responsible for innovation? } \\
\text { Ima li vaša tvrtka odjel / službenika odgovornoga za inovacije? }\end{array}$ & 647 \\
\hline 2. & $\begin{array}{l}\text { Do you have a system in place to develop your human resources in relation to innovation? } \\
\text { Imate li sustav za razvoj ljudskih resursa vezanih za razvoj inovacija? }\end{array}$ & 622 \\
\hline 3. & $\begin{array}{l}\text { If you are active in the field of eco-innovations development, to which of the listed elements do your } \\
\text { eco-innovation developments relate to: product, service, production process, supply chain, other? } \\
\text { Ako ste aktivni u području razvoja ekoinovacija, na koji se od navedenih elemenata odnosi razvoj } \\
\text { vaših ekoinovacija: na proizvod, na usluge, na proces proizvodnje, na opskrbni lanac ili na nešto } \\
\text { drugo? }\end{array}$ & 513 \\
\hline 4. & $\begin{array}{l}\text { If you are active in the field of eco-innovations, select the appropriate stage of development of your } \\
\text { firm: } \\
\text { - Already developed and in use } \\
\text { - In design stage } \\
\text { - In development stage } \\
\text { Ako ste aktivni u području ekoinovacija, odaberite odgovarajući stupanj razvoja ekoinovacija u } \\
\text { vašoj tvrtki: } \\
\text { - već su razvijene i primjenjuju se } \\
\text { - u fazi su projektiranja } \\
\text { - u razvojnoj su fazi. }\end{array}$ & $\begin{array}{l}382 \\
380 \\
383\end{array}$ \\
\hline 5. & $\begin{array}{l}\text { To which of the listed areas do your eco-innovations relate to: Energy efficiency, Closed-loop } \\
\text { recycling, Renewable resources, Natural materials, Water consumption, New materials, Other, Food } \\
\text { and beverage processing? } \\
\text { Na koje se od navedenih područja odnose vaše ekoinovacije: na energetsku učinkovitost, na } \\
\text { recikliranje, na obnovljive izvore, na prirodne materijale, na potrošnju vode, na nove materijale, na } \\
\text { ostalo, na proizvodnju hrane i pića? }\end{array}$ & 335 \\
\hline 6. & $\begin{array}{l}\text { Are you applying the principles of eco-design by developing new product/service? } \\
\text { Primjenjujete li načela ekodizajna u razvoju novog proizvoda/usluge? }\end{array}$ & 344 \\
\hline 7. & $\begin{array}{l}\text { If you are applying the principles of eco-design, select the reasons why you decided to do so } \\
\text { (multiple answers are possible). } \\
\text { Ako primjenujete načela ekodizajna, odaberite razloge zbog kojih ste se odlučili da to činite (moguće } \\
\text { je više odgovora). }\end{array}$ & 312 \\
\hline 8. & $\begin{array}{l}\text { If you are not using the principles of eco-design, select the reasons why (multiple answers are } \\
\text { possible). } \\
\text { Ako ne primjenjujete načela ekodizajna, odaberite razloge zašto se njima ne koristite (moguće je više } \\
\text { odgovora). }\end{array}$ & 232 \\
\hline
\end{tabular}

oped by a research group of experts of architecture, wood technology, managemnet, design, and construction. A web survey approach based on the procedures recommended by Dillman (2000) allowed for data collection over a broad geographic area and for low cost data entry. The questions relate to EU indicators of innovations, and innovation management systems. The survey was pre-tested to ensure clarity and practicability with several companies.

The web-based survey (Dillman, 2000; Evans and Mathur, 2005) was administered between $9^{\text {th }}$ July 2012, to $31^{\text {st }}$ August 2012. 712 invitations to participate were sent out. The Ministry of Economic Development and Technology provided hosting for the survey.

In addtion to demographic questions, 8 questions related to company attitudes and activities related to innovation management, eco-innovation and eco-design were asked in the survey (see Table 1).

\subsection{Sample}

\subsection{Uzorak}

The sample consisted of 712 production and service oriented Slovenian companies registered as members of the Chamber of Commerce and Industry in Slo- venia. The manager responsible for production was the target person of the survey. In total 657 questionnaires were completed, resulting in a response rate of $92 \%$. Due to the unusually high response rate, nonresponse bias was not assessed. However, not all participants responded to all questions. In many cases this is because not all questions were applicable to all respondents. For example, only 513 respondents reported participating in eco-innovations; therefore, only these respondents completed questions specifically about the ecoinnovations of their company.

\section{RESULTS AND DISCUSSION 3. REZULTATI I RASPRAVA}

3.1 Respondent demographics

3.1. Podaci o tvrtkama koje su odgovorile na anketu

The majority of respondents $(60 \%)$ were micro sized organisations (1-10 employes), but representatives of small (11-50 employees), medium (51-250 employees), and large (more than 250 employees) firms also responded (see Table 2). Respondents represented firms in the manufacturing sector $(27 \%)$, the professional, scientific and technical activities sector (25\%), 
Table 2 Respondent company demographics

Tablica 2. Podaci o tvrtkama koje su odgovorile na anketu

\begin{tabular}{|l|c|c|c|c|}
\hline $\begin{array}{l}\text { Company size } \\
\text { Veličina tvrtke }\end{array}$ & $\begin{array}{c}\text { Employees } \\
\text { Broj zaposlenih }\end{array}$ & $\begin{array}{c}\text { Annual revenue, EUR, millions } \\
\text { Godišnji prihod, mil. EUR }\end{array}$ & $\begin{array}{c}\text { Frequency } \\
\text { Učestalost }\end{array}$ & $\begin{array}{c}\text { Percent, \% } \\
\text { Udjel, \% }\end{array}$ \\
\hline Micro / mikro & $1-10$ & $<2$ & 427 & 60 \\
\hline Small / mala & $11-50$ & $<10$ & 108 & 15 \\
\hline Medium / srednja & $51-250$ & $<250$ & 104 & 15 \\
\hline Large / velika & $>250$ & $>250$ & 73 & 10 \\
\hline & & Total / Ukupno & 712 & 100 \\
\hline
\end{tabular}

Table 3 Responsible for innovations

Tablica 3. Osobe odgovorne za inovacije

\begin{tabular}{|l|c|c|}
\hline Gender / Spol & $\begin{array}{c}\text { Frequency } \\
\text { Učestalost }\end{array}$ & $\begin{array}{c}\text { \% of responses } \\
\text { (\% of total) } \\
\text { Postotak odgovora } \\
\text { (od ukupnog broja) }\end{array}$ \\
\hline Female /žene & 102 & $70(33)$ \\
\hline Male / muškarci & 236 & $30(14)$ \\
\hline Total / Ukupno & 338 & $100(47)$ \\
\hline
\end{tabular}

Table 4 Age of the person responsible for innovation Tablica 4. Starost osoba odgovornih za inovacije

\begin{tabular}{|l|c|c|}
\hline \multicolumn{1}{|c|}{$\begin{array}{c}\text { Age } \\
\text { Starost }\end{array}$} & $\begin{array}{c}\text { Frequency } \\
\text { Učestalost }\end{array}$ & $\begin{array}{c}\text { \% of responses (\% of total) } \\
\text { Postotak odgovora (od } \\
\text { ukupnog broja) }\end{array}$ \\
\hline $21-40$ & 145 & $43(20)$ \\
\hline $41-60$ & 174 & $52(24)$ \\
\hline $\begin{array}{l}\text { Over } 60 \\
\text { stariji od } 60\end{array}$ & 18 & $5(2)$ \\
\hline Total /Ukupno & 337 & $100(46)$ \\
\hline
\end{tabular}

the information and communications sector (14\%), and the construction sector (11\%), and $23 \%$ belonged to other sectors. Of those who shared gender and age information of the person responsible for innovation, the responsible persons were mostly male, and between the age of 21-60 (see Table 3 and Table 4). Furthermore, the responsible persons mostly held university degrees (39\%), a scientific masters degree or a doctorate $(24 \%)$. Furthermore, $12 \%$ held higher education degree, $9 \%$ college degree, $12 \%$ high school degree, and $2 \%$ vocational school degree. Most responding companies were from the Gorenjska and Osrednjaslovenska regions (see Fig. 3). This is unsurprising, as these regions are the Ljubljana metropolitan areas and have the highest populations and a dense concentration of businesses.

\subsection{Innovation support \\ 3.2. Potpora inovacijama}

We wanted to know if there was a responsible innovation officer, developer or an innovator for innovations, so the question if the company has a department or officer responsible for innovation was answered by $90 \%$ of respondents. Many companies have established an innovative environment for sustainable development or support for eco-innovation and innovation processes. Yet, the majority of companies (51\%) do not have an officer or department specifically responsible for innovation. Most of the companies, reporting structural innovation support, have a staff

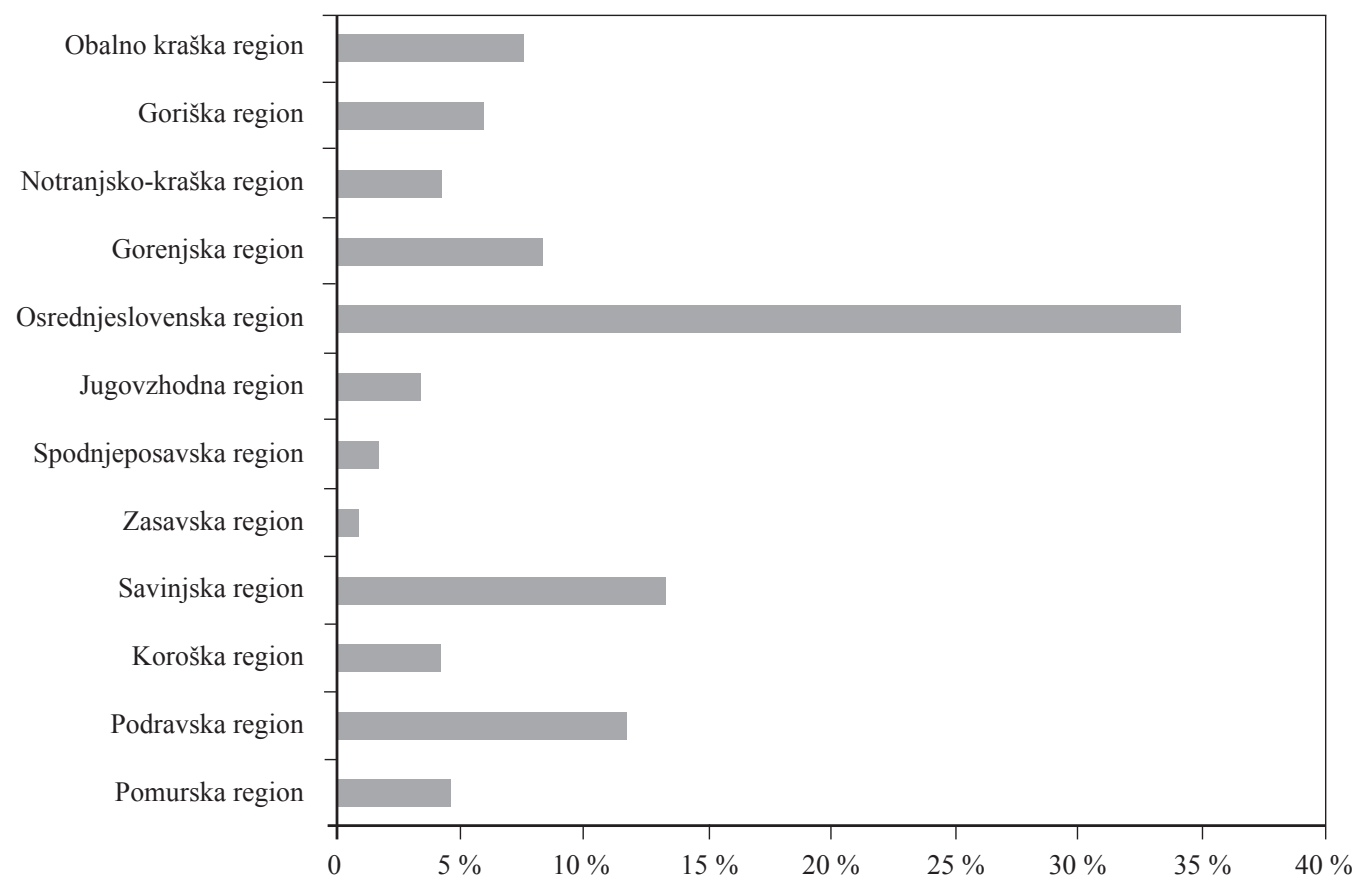

Figure 3 Respondents' company location $(n=344)$

Slika 3. Lokacija tvrtki koje su odgovorile na anketu $(n=344)$ 


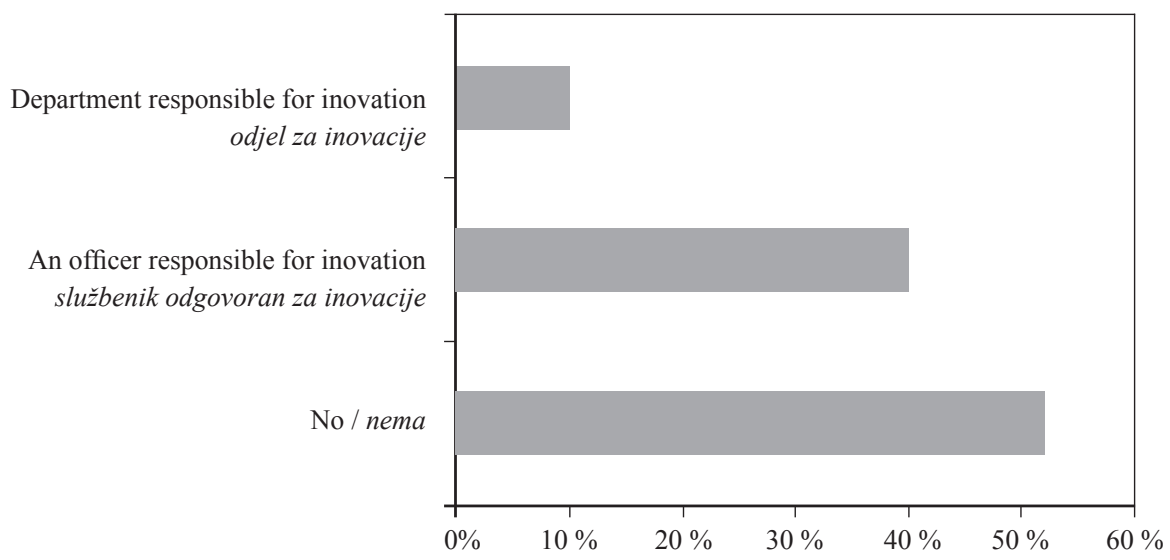

Figure 4 Responses to the question "Does your company have a department/officer responsible for innovation?" $(n=647)$

Slika 4. Odgovori na pitanje Ima li vaša tvrtka odjel/službenika odgovornoga za inovacije? $(n=647)$

member responsible for innovation (39\%), while just over $10 \%$ of the survey respondents have a department responsible for innovation (see Fig. 4).

\subsection{Types of eco-innovation and the stage of their development}

3.3. Vrste ekoinovacija i stupanj njihova razvoja

It was found that $72 \%$ of total responses of the enterprises participating in the survey actively pursue eco-innovations. Furthermore, the majority of eco-innovations in development by Slovenian enterprises relate to products, services and production processes, while a smaller share relate to the supply chain. The vast majority of companies active in the area of eco-innovation focus on products $(55 \%)$ and services $(48 \%)$. The proportion of those focusing on production processes in the area of eco-innovation is relatively high (39\%), while the proportion focusing on eco-innovation in the supply chain is relatively low (14\%) (see Fig. 5).

The main arguments given for not investing in innovation were the company's small size, the newness

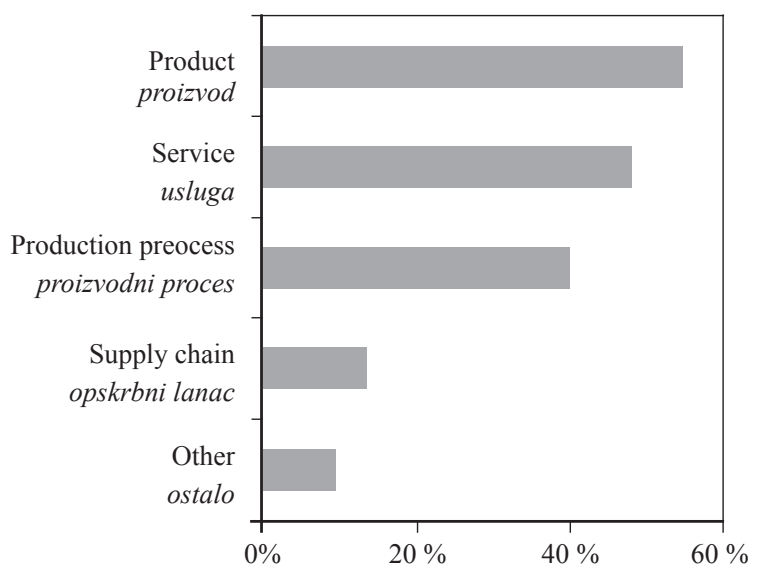

Figure 5 Answers to the question "If you are active in the field of eco-innovation development, to which of the listed elements do your eco-innovation developments relate to?" $(n=513)$

Slika 5. Odgovori na pitanje Ako ste aktivni u razvoju ekoinovacija, na koju se od navedenih sastavnica odnosi razvoj vaših ekoinovacija? $(n=513)$ of the company, a lack of financial resources for research and development of more sustainable products, no political control or support of sustainable companies, etc. Small companies cited their small size (some surveyed companies have only one employee), their lack of financial resources to dedicate to innovation, that innovation is not needed, or that consumer education about responsible product properties takes too much time. Medium sized enterprises showed great concern about regulations, a lack of political support and the expense of qualified human resources. These concerns demonstrate the need for outside support (from the government, from NGO's, from the EU or wherever, as long as you can support it).

As stated before, Slovenia has not identified ecoinnovation as a priority means to simultaneously improve national economic competitiveness, while also developing new products and services. The results of the survey further emphasize the need for systematical aproach into investments of eco-innovations and ecodesign on the national level, including support defined in national priorites and action plans. Eco-innovation development progress is similarly distributed between innovations that have already been developed and are in use, those in the design stage, and those in the development stage.

The survey results revealed that the majority of respondents focus on energy efficiency eco-innovations (59\%). Addtionally, many firms are active in ecoinnovations related to closed-loop recycling and renewable resources (39\% each) (see Table 5). Although 513 respondents responded that they are active in the field of eco-innovation, only 335 provided categorical information about their innovations. Energy efficiency investments are not surprising given Europe's prioritization of this topic, and its clear path to cost reductions. The closed-loop recycling concept is a valuable eco-design concept that can help companies compete and achieve market success. 'Closed-loop recycling' reduces a company's dependence on raw materials, and probably many firms are innovating this area. In order to meet environmental challenges such as climate change, much attention has been paid to innovation as 
Table 5 Companies that reported focusing their eco-innovations on specific categories $(n=335)$

Tablica 5. Broj tvtrki koje su odgovorile da su njihove ekoinovacije vezane za određenu kategoriju $(n=335)$

\begin{tabular}{|l|c|c|}
\hline $\begin{array}{l}\text { Eco-innovation category } \\
\text { Kategorija ekoinovacija }\end{array}$ & $\begin{array}{c}\text { Frequency } \\
\text { Broj odgovora }\end{array}$ & $\begin{array}{r}\text { \% of responses (\% of total) } \\
\text { Postotak odgovora (od ukupnog broja) }\end{array}$ \\
\hline Energy efficiency / energetska učinkovitost & 197 & $59(26)$ \\
\hline Closed-loop recycling / recikliranje & 129 & $39(17)$ \\
\hline Renewable resources / obnovljivi izvori & 131 & $39(17)$ \\
\hline Natural materials / prirodni materijali & 94 & $28(12)$ \\
\hline Water consumption / potrošnja vode & 90 & $27(12)$ \\
\hline New materials / novi materijali & 61 & $18(8)$ \\
\hline Other / ostalo & 45 & $7(3)$ \\
\hline Food and beverage processing / proizvodnja hrane i pića & 24 & \\
\hline Total / Ukupno & 771 & \\
\hline
\end{tabular}

a way to use renewable resources. Additional information provided along with the 'Other category' included citing: agriculture, alternative processes, spatial planning, organic cleaners, reduction of $\mathrm{CO}_{2}$, healthy living environments, waste separation, noise analyses, and paper consumption, amongst others, as their eco-innovation focus areas.

\subsection{Enterprises applying the principles of eco- design}

3.4. Poduzeća koja primjenjuju načela ekodizajna

Seventy-six percent of responding enterprises (262 out of 344) apply principles of eco-design. Figure 6 summarizes the most frequent reasons (and associated weights) for doing so. The most common supporting argument was to reduce the impact on the environment. Reducing the environmental impact of product

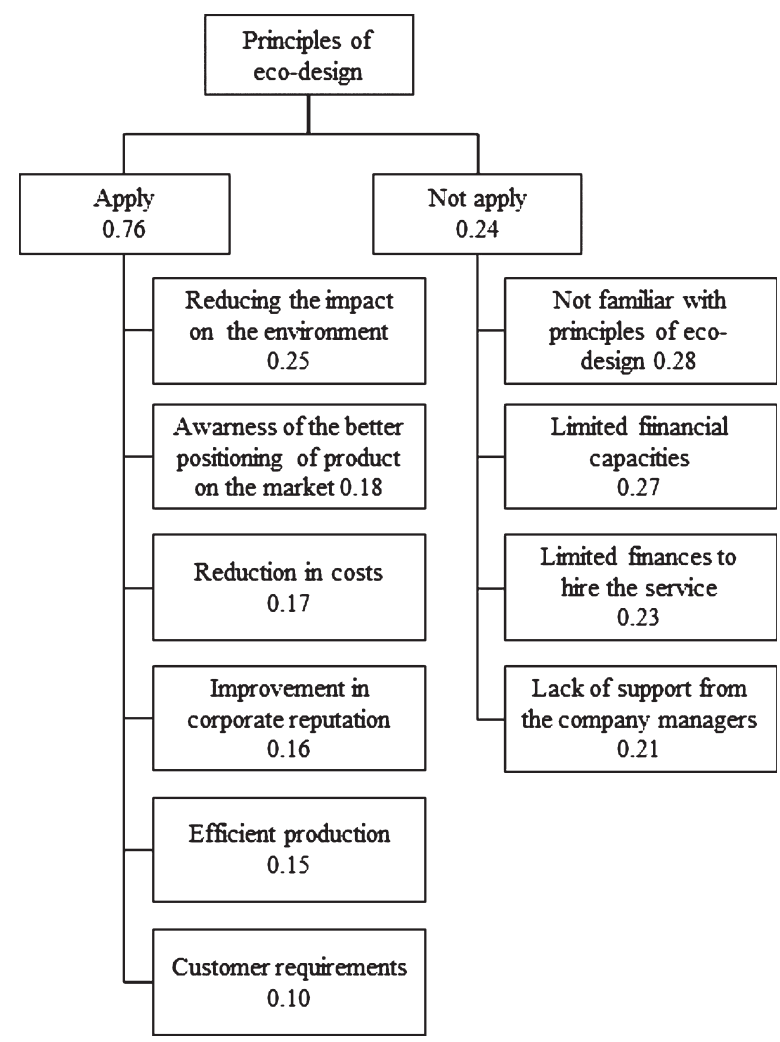

Figure 6 Diagram of weights of reasons for apllying and not applying the principles of eco-design

Slika 6. Dijagram pondera razloga za primjenu ili neprimjenu načela ekodizajna may stem from legislative requirements, project and client requirements, corporate awareness for the importance of eco-design in environmental protection. Other frequent answers were an awareness for the marketing potential of environmentally friendly products, competitive advantage, reductions in cost, and improvements in corporate reputation.

Respondents who do not currently apply eco-design principles (82) most commonly stated they are not familiar with principles of eco-design and they are still studying this area, that they have limited financial capacities, eco-inovations are in the process of being introduced, that they are waiting for a response from the market in a sense of buying more sustainable products. They also mentioned that they have limited financial capacities, that it is too expensive and that they do not have sufficient skills at their disposal. Some potential solutions are training courses for managers and other employees, EU/National grants or hiring trained professionals working more closely with research organizations. There is also a lack of support from the company managers who do not recognize the market potentional of eco-innovative products and technologies.

\section{CONCLUSIONS \\ 4. ZAKLJUČAK}

The survey of more than 650 executives revealed that less than half of responding Slovenian enterprises have established an innovative environment for sustainable development or support for eco-innovation and innovation processes. The majority of eco-innovations in development in Slovenian enterprises relate to products, services and production processes, while a smaller share relate to the supply chain. The results of the survey should be used in preparation of further more in-depth interviews for companies. They could be used in preparation of further documents, like action plans and strategies in the field of eco-innovations and eco-design. The decision makers in Slovenia should support enterprises in their eco-innovation activities and continue with implementation of the initiatives, action plans and strategies in research and development and innovation, with the focus on eco-innovation. The results may have implications for the wood sector firms as the emphasis on renewable resources becomes 
mainstream. Additionally, the government should support eco-innovation by public tender calls, following the European CIP Eco-innovation, and support clusters of applicants and projects which demonstrate an added value and have a high potential for market replication. Clearly, national policies on eco-innovation need to be underpinned by international agreements that all countries will take action to reduce their environmental impacts. The right government policy is needed to ensure synergies between business, science, culture and the environment, which would support the clusters able to jointly deliver successful eco-innovations.

In order to become leaders in eco-design, Slovenian enterprises will have to overcome several challenges, including training designers and strengthening their role, and motivating companies to invest in new, innovative approaches by combining commercial, environmental and social benefits. Only industries focusing on eco-innovations can contribute to the EU goal to become a smart, sustainable, and inclusive economy. Furthermore, eco-design is an important tool for reducing the environmental impact of new products and services, contributes to the creation of products with higher added value and is closely linked with the development of ecoinn ovation. The capacity of eco-innovations to provide new business opportunities and contribute to the transformation towards a sustainable society depends on the interplay of listed activities and the engagement of key stakeholders in the innovation process. Only enterprises able to successfully innovate are likely to dominate and prosper in the new markets they create and can position themselves to master change.

\section{Acknowledgements - Zahvala}

The authors acknowledge the Ministry of Economic Development and Technology, Republic of Slovenia for sharing the survey results. Author Manja Kitek Kuzman wishes to thank the Slovenian Research Agency, program P4-0015-0481 and Ministry of Education, Science and Sport RS in the frame of the WoodWisdom-Net? Project W3B Wood Believe. Martina Zbašnik-Senegačnik would like to acknowledge the Slovenian Research Agency for financial support within the frame of the program P5-0068.

\section{REFERENCES}

\section{LITERATURA}

1. Baumgartner, R. J., 2011: Critical perspectives of sustainable development research and practice. Journal of Cleaner Production, 19: 783-786. http://dx.doi. org/10.1016/j.jclepro.2011.01.005.

2. Berginc, J.; Hrovatin, J.; Feltrin, M.; Maechtig, S. J.; Zupančič, A.; Oblak, L., 2011: Analysis of cooperation between furniture industry and designers in product development process. Drvna industrija, 62 (2): 129-136. http://dx.doi.org/10.5552/drind.2011.1106.

3. Braungart, M.; McDonaugh, W.; Bollinger, A., 2007: Cradle-to-cradle design: creating healthy emissions e a strategy for eco-effective product and system design. Journal of Cleaner Production, 15: 1337-1348. http://dx.doi.org/10.1515/9783034611398.247.
4. Barčić Pirc, A.; Motik, D., 2013: Innovation and Innovativeness in Medium-Low Tech/Low-Tech Industries Wood Industry. Drvna industrija, 64: 247-255.

http://dx.doi.org/10.5552/drind.2013.1301.

5. Berkhout, F.; Smith, D., 1999: Products and the environment: an integrated approach to policy. European Environment, 9: 174-185.

http://dx.doi.org/10.1002/(sici)1099-0976(199909/10) 9:5<174::aid-eet204>3.3.co;2-y.

6. Carrillo-Hermosilla, J.; del Río, P.; Könnölä, T., 2010: Diversity of eco-innovations: Reflections from selected case studies. Journal of Cleaner Production, 18: 10731083. http://dx.doi.org/10.1016/j.jclepro.2010.02.014.

7. Charter, M.; Clark, T.; 2007: Sustainable Innovation. The Centre for Sustainable Design, University College for the Creative Arts, Farnham, UK.

8. Dillman, D. A., 2000: Mail and Internet Surveys-The Tailored Design Method. $2^{\text {nd }}$ ed. John Wiley \& Sons, Inc., New York.

9. Evans, J. R.; Mathur, A., 2005: The value of online surveys. Internet Research 15 (2): 195-219. http://dx.doi. org/10.1108/10662240510590360.

10. Fussler, C.; James, P., 1996: Eco-innovation: A Breakthrough Discipline for Innovation and Sustainability. Pitman Publishing, London.

11. Glavonjić, B.; Oblak, L., 2012. Consumption of woody biomass in industry, commercial and public facilities in Serbia: present state and possible contribution to the share of renewable sources in final energy consumption. Therm. sci., 16 (1): 7-19. http://dx.doi.org/10.2298/TSCI1201007G.

12. Green, K.; McMeekin, A.; Irwin, A., 1994: Technological trajectories and R\&D for environmental innovation in UK firms. Futures, 26: 1047-1059. http://dx.doi.org/10.1016/0016-3287(94)90072-8.

13. Klewitz, J.; Hansen, E. G., 2014: Sustainability-oriented innovation of SMEs: a systematic review. Journal of Cleaner Production, 65: 1-19. http://dx.doi.org/10.1016/j. jclepro.2013.07.017.

14. Massard, G.; Jacquat, O.; Zürcher, D., 2014: International survey on eco-innovation parks. Learning from experiences on the spatial dimension of eco-innovation. Federal Office for the Environment FOEN and the ERA-NET ECO-INNOVERA, Bern.

15. Oblak, L.; Glavonjić, B., 2014: A model for the evaluation of radio advertisement for the sale of timber products. Drvna industrija, 65 (4): 303-308. http://dx.doi. org/10.5552/drind.2014.1357.

16. Oblak, L.; Jošt, M., 2011: Methodology for studying the ecological quality of furniture, Drvna industrija, 62: 171176. http://dx.doi.org/10.5552/drind.2011.1038.

17. Ojurović, R.; Moro, M.; Šegotić, K.; Grladinović, T.; Oblak, L., 2013: Analysis of the investment in wood processing and furniture manufacturing entities by key factors of competitiveness. Drvna industrija, 64 (2): 131137. http://dx.doi.org/10.5552/drind.2013.1235.

18. Pirc Barčić, A.; Vlosky, R.; Motik, D., 2011: Deconstructing Innovation: An Exploratory Study of the US Furniture Industry. Forest Product Journal, 61 (8): 635643. http://dx.doi.org/10.13073/0015-7473-61.8.635.

19. Pujari, D., 2006: Eco-innovation and new product development: understanding the influences on market performance. Technovation, 26: 76-85. http://dx.doi.org/10.1016/j.technovation.2004.07.006.

20. Rademaekers, K.; van der Laan, J.; Widerberg, O.; Zaki, S.; Klaassens, E.; Smith, M.; Steenkamp, C., 2012: The number of Jobs dependent on the Environment and Re- 
source Efficiency improvements, Final report. Ecorys, Rotterdam.

21. Rehfeld, K. M.; Rennings, K.; Ziegler, A., 2007: Integrated product policy and environmental product innovations: An empirical analysis. Ecological economics, 61 (1): 91-100.

http://dx.doi.org/10.1016/j.ecolecon.2006.02.003.

22. Rennings, K.; Ziegler, A.; Ankele, K.; Hoffmann, E., 2006: The influence of different characteristics of the EU environmental management and auditing scheme on technical environmental innovations and economic performance. Ecological Economics, 57: 45-59.

http://dx.doi.org/10.1016/j.ecolecon.2005.03.013.

23. Toppinen, A.; Toivonen, R.; Valkeapää, V.; Rämö, A.-K., 2013: Consumer perceptions of environmental and social sustainability of wood products in the Finnish market. Scandinavian Journal of Forest Research, 28: 775-783. http://dx.doi.org/10.1080/02827581.2013.824021.

24. ***2013: "CIP Eco-innovation" (online), http:// ec.europa.eu/environment/eco-innovation/files/docs/ publi/first_overview_of_the_call_2013_cip_eco-innovation.pdf (Accessed June, 15, 2015).

25. ***2014: "Eco-innovation observatory" (online), http:// www.eco-innovation.eu (Accessed Sept. 21, 2015).

26. ***2014: "An Integrated Industrial Policy for the Globalisation Era, Putting Competitiveness and Sustainability at Centre Stage" (online), European Commission, http://eur-lex.europa.eu/legal-content/EN/TXT/?uri= URISERV:et0005 (Accessed July 4, 2015).

27. ***2011: "EU environment policy supporting jobs and growth", European Commission, http://ec.europa.eu/environment/enveco/industry_employment/pdf/ facts_and_figures.pdf(Accessed July 4, 2015).
28. ***2011a: "Attitudes of European entrepreneurs towards eco-innovation, Analytical report", European Commission, http://ec.europa.eu/public_opinion/flash/fl_315_ en.pdf (Accessed Aug.7, 2015).

29. ***2013: "Enterprise and Industry", European Commission, http://ec.europa.eu/enterprise/index en.htm (Accessed Aug. 7, 2015).

30. *** 2013: "SMEs, resource efficiency and green markets", Flash Eurobarometer 381. http://ec.europa.eu/public_opinion/flash/fl_381_sum_en.pdf (Accessed July 4, 2015).

31. ***2009: "Sustainable Manufacturing and Eco-Innovation. Framework, Practices and Measurement", OECD, Synthesis Report, http://www.oecd.org/innovation/ inno/43423689.pdf (Accessed Sept. 5, 2015).

32. ***2012: "The Eco-innovation action plan (EcoAP)", http:/ec.europa.eu/environment/ecoap/about-actionplan/index_en.htm. (Accessed June 15, 2015).

\section{Corresponding address:}

Assoc. Prof. MARTINA ZBAŠNIK-SENEGAČNIK, Ph.D.

University of Ljubljana

Faculty of Arhitecture

Zoisova ulica 12

1000 Ljubljana, SLOVENIA

e-mail: martina.zbasnik@fa.uni-lj.si 